\title{
Effective Nutrient Combination for Advance Capsularis Breeding Line BJC-5050 Production
}

\author{
Md. Marfudul Hoque ${ }^{1,2 *}$, Md. Saheb Ali ${ }^{1}$, Md. Abdul Alim ${ }^{1}$, Bornali Mostofa ${ }^{1}$, \\ Md. Mahbubul Islam ${ }^{1,3}$ \\ ${ }^{1}$ Bangladesh Jute Research Institute, Manik Mia Ave., Dhaka, Bangladesh \\ ${ }^{2}$ Agriculture Extension Officer, Department of Agriculture Extension Kaptai, Rangamati, Bangladesh \\ ${ }^{3} \mathrm{CSO} \&$ Head, PTC Division, Bangladesh Jute Research Institute, Bangladesh \\ marfudulhoque7@gmail.com
}

\begin{abstract}
Nutrient requirement has been optimized for the cultivation of advanced breeding line BJC-5050 in Bangladesh. Different nutrient levels influenced the yield contributing characters which ultimately increased the fibre and stick yield over control. Among the nitrogen doses, the rate $100 \mathrm{~kg} \mathrm{~N} / \mathrm{ha}$ demonstrated significantly tallest plant $(3.17 \mathrm{~m})$, highest base diameter $(17.34 \mathrm{~mm})$, fibre $(2.81 \mathrm{t} / \mathrm{ha})$ and stick $(7.06 \mathrm{t} / \mathrm{ha})$ yield. The highest yield of fibre and stick were found with the dose of $15 \mathrm{~kg} \mathrm{P} / \mathrm{ha}$. The K level up to $45 \mathrm{~kg} / \mathrm{ha}$ influenced the yield and yield contributing characteristics over the control. The tallest plant was found with $30 \mathrm{~kg} \mathrm{~K} / \mathrm{ha}$ which was statistically identical the treatments other than treatments of $\mathrm{T}_{1}, \mathrm{~T}_{2}, \mathrm{~T}_{5}$, and $\mathrm{T}_{9}$. The significant highest fibre yield was induced by $\mathrm{K} 30 \mathrm{~kg} / \mathrm{ha}$. In case of S results showed significant yield increase with different rates over the control. It indicates that $20 \mathrm{~kg} \mathrm{~S} / \mathrm{ha}$ is enough in producing highest yield of fibre and stick. Study revealed that combined dose of NPKS 100-15-30-20 kg/ha may be a suitable dose for the cultivation of advance breeding line BJC-5050.
\end{abstract}

\section{INTRODUCTION}

Fiber yield step up and quality of jute is the prime need of Bangladesh. Jute fibre was produced annually from an average area of 4.50-5.00 lakh ha of land in Bangladesh [1]. But the area and production was increased significantly from 2010-2011 and onwards due to developing more conscious about environment and stepping forward to the natural fibre by escaping from the perilous impact of synthetic fibre to the environment. As a result demand of jute fibre is being increased in the recent years both in home and abroad. In this aspect, research regarding development of new high yielding variety of jute and determination of its fertilizer requirement is very important. In actual fact, these requirements vary within the same type of crop. For example, fertilizer requirement of capsularis line is lower than that of olitorius. The importance of $\mathrm{N}, \mathrm{P}, \mathrm{K}$ and $\mathrm{S}$ on the growth, yield and quality of fiber crops is well established [2-12]. It is necessary to find a fertilizer combination which is economically profitable and at the same time gives yield very close to maximum yield potential. Therefore, much attention should be given towards the improvement of yield and quality of jute fiber to bring back the past glory of Bangladeshi jute. Considering the above facts the present study has been undertaken to observe the effects of N, P, K and S fertilizers on the growth, yield and quality of the advance breeding line, BJC-5050 and to find out the optimum requirement of all of these nutrients to achieve the maximum yield potential of this new advance breeding line, BJC-5050.

\section{Materials AND METhods}

The research was carried out at the Jute Agricultural Experimental Station (JAES) of Bangladesh Jute Research Institute, under Sadar Upazila of Manikganj district. The experiment was laid out in randomized complete 


\section{Effective Nutrient Combination for Advance Capsularis Breeding Line BJC-5050 Production}

block design with three replications. A total 10 treatment combinations along with a control were distributed randomly in each plot as one replication (Table 1). The dimension of unit plots was $3.1 \mathrm{~m} \times 3.1 \mathrm{~m}$ having $1 \mathrm{~m}$ space between the plots, blocks and around the field. There was $20 \mathrm{~cm}$ deep drain around each block and plot. Each replication was divided into 10 unit plots and the total land required of $13.3 \mathrm{~m} \times 42 \mathrm{~m}$. At the beginning of the experiment, the land was well prepared and fertilizers were applied as per treatment.

Table1. Treatment combinations (NPKS in $\mathrm{Kg} / \mathrm{ha}$ )

\begin{tabular}{|c|c|}
\hline $\mathrm{T}_{1}: \mathrm{N}_{0} \mathrm{P}_{10} \mathrm{~K}_{30} \mathrm{~S}_{20}$ & $\mathrm{~T}_{6}: \mathrm{N}_{100} \mathrm{P}_{15} \mathrm{~K}_{30} \mathrm{~S}_{20}$ \\
\hline $\mathrm{T}_{2}: \mathrm{N}_{75} \mathrm{P}_{10} \mathrm{~K}_{30} \mathrm{~S}_{20}$ & $\mathrm{~T}_{7}: \mathrm{N}_{100} \mathrm{P}_{10} \mathrm{~K}_{0} \mathrm{~S}_{20}$ \\
\hline $\mathrm{T}_{3}: \mathrm{N}_{100} \mathrm{P}_{10} \mathrm{~K}_{30} \mathrm{~S}_{20}$ & $\mathrm{~T}_{8}: \mathrm{N}_{100} \mathrm{P}_{10} \mathrm{~K}_{45} \mathrm{~S}_{20}$ \\
\hline $\mathrm{T}_{4}: \mathrm{N}_{125} \mathrm{P}_{10} \mathrm{~K}_{30} \mathrm{~S}_{20}$ & $\mathrm{~T}_{9}: \mathrm{N}_{100} \mathrm{P}_{10} \mathrm{~K}_{30} \mathrm{~S}_{0}$ \\
\hline $\mathrm{T}_{5}: \mathrm{N}_{100} \mathrm{P}_{0} \mathrm{~K}_{30} \mathrm{~S}_{20}$ & $\mathrm{~T}_{10}: \mathrm{N}_{100} \mathrm{P}_{10} \mathrm{~K}_{30} \mathrm{~S}_{15}$ \\
\hline
\end{tabular}

Required amounts of N, P, K, S fertilizers were applied in the form of urea, TSP, MoP and gypsum. Half of Urea was applied at sowing and the rest half was top dressed at 45 days after sowing while all other fertilizers were applied at the time of sowing. Jute seeds were broadcasted at the rate of $8 \mathrm{~kg} / \mathrm{ha}$. All cultural operations were done as and when necessary. The crop was harvested when $80 \%$ of the plants showed the sign of maturity. After shedding of leaves, the bundles were steeped plot-wise in pond water for 15-20 days for retting and fiber was extracted. At harvesting time, six plants were selected at random from each plot and tagged in the field to note plant height (PH), base diameter (BD), fiber yield (FY) and stick yield (SY). Statistical [13] and economic analyses were also carried out.

\section{RESULTS AND DiscusSion}

Combined chemical fertilizers demonstrated significant positive effect on all the growth parameter like plant height (Figure 1), base diameter (Figure 2). The maximum plant height (3.17 m), base diameter (17.34 mm) were found by the treatment $\mathrm{T}_{6}\left(\mathrm{~N}_{100} \mathrm{P}_{15} \mathrm{~K}_{30} \mathrm{~S}_{20} \mathrm{~kg} / \mathrm{ha}\right)$. Application of different treatments showed statistically significant positive effect on fibre yield (FY) and stick yield (SY) of jute. Highest FY (2.81 t/ha) and SY (7.06 t/ ha) were reported with $\mathrm{T}_{6}\left(\mathrm{~N}_{100} \mathrm{P}_{15} \mathrm{~K}_{30} \mathrm{~S}_{20} \mathrm{~kg} / \mathrm{ha}\right)$ treatment.

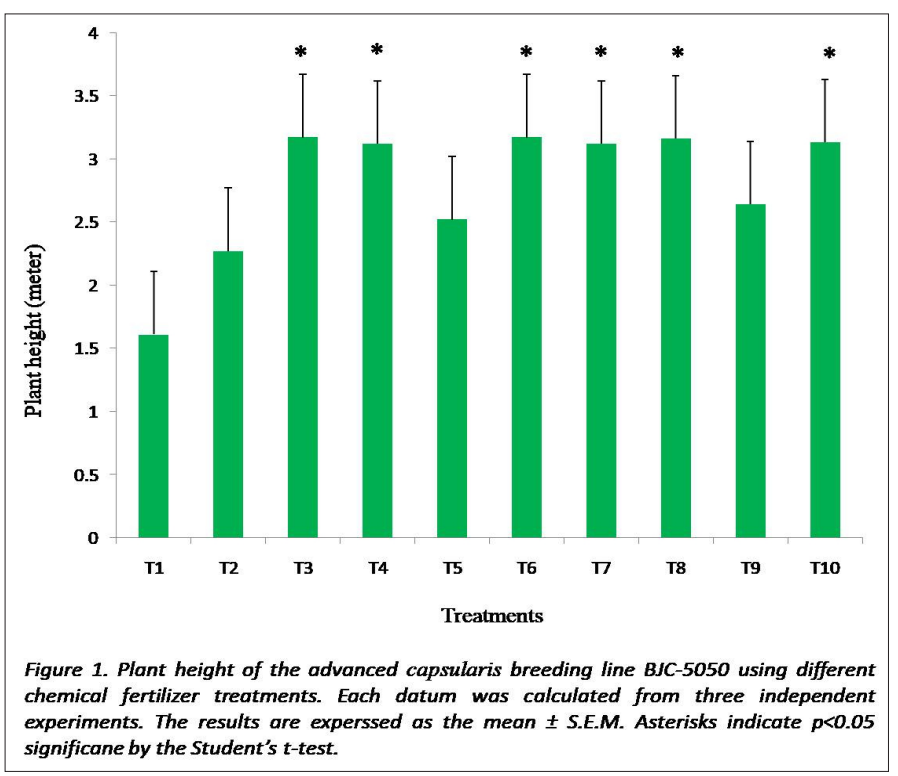

American Research Journal of Agriculture

Page 2 


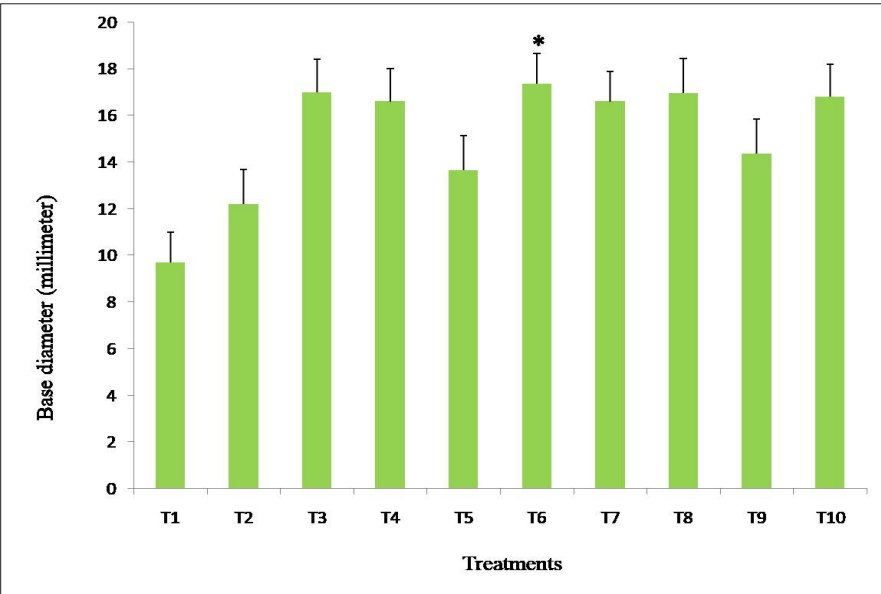

Figure 2. Base diameter of the advanced capsularis breeding line BJC-5050 using different chemical fertilizer treatments. Each datum was calculated from three independent experiments. The results are experssed as the mean \pm S.E.M. Asterisks indicate $p<0.05$ significane by the Student's $t$-test.
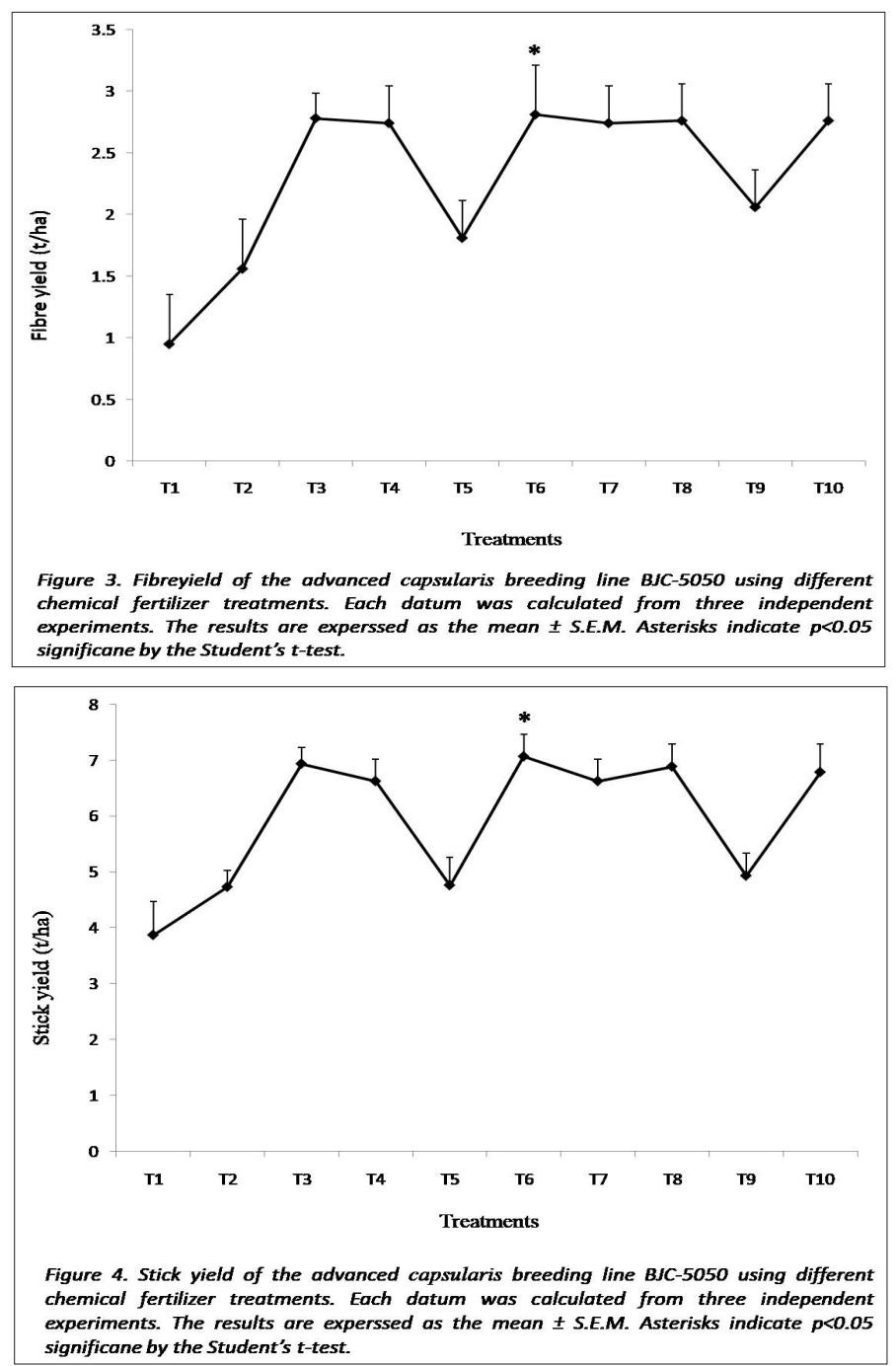


\section{Effect of Nitrogen}

Yield contributing characters were influenced by nitrogen levels which ultimately increased the fibre and stick yield over control. Among the nitrogen doses, the rate $100 \mathrm{~kg} \mathrm{~N} /$ ha demonstrated significantly tallest plant $(3.17 \mathrm{~m})$, highest base diameter $(17.34 \mathrm{~mm})$, fibre (2.81t/ha) and stick (7.06t/ha) yield. The dose of $100 \mathrm{~kg} \mathrm{~N} / \mathrm{ha}$ might be an effective dose for producing BJC-5050.

\section{Effect of Phosphorus}

Different $\mathrm{P}$ rates influenced to plant height, base diameter, yield of fibre and stick over control. The highest yield of fibre (2.81t/ha) and stick yield (7.06t/ha) found with the dose of $15 \mathrm{~kg} P /$ ha. Results exposed that the dose of $15 \mathrm{~kg} \mathrm{P} /$ ha will be sufficient to grow BJC-5050.

\section{Effect of Potassium}

The tallest plant $(3.17 \mathrm{~m})$ was found with $\mathrm{K} 30 \mathrm{~kg} / \mathrm{ha}\left(\mathrm{T}_{7}\right)$ which was statistically similar with $\mathrm{T}_{3,}, \mathrm{~T}_{4}, \mathrm{~T}_{7}, \mathrm{~T}_{8}$, and $\mathrm{T}_{10}$, Significantly highest fibre yield was induced by $\mathrm{K} 30 \mathrm{Kg} / \mathrm{ha}(2.81 \mathrm{t} / \mathrm{ha})$. Taking into consideration the findings that the dose of $\mathrm{K} 30 \mathrm{~kg} / \mathrm{h}$ a will be a sufficient to produce the advance breeding line BJC-5050. Study revealed that the advance breeding line BJC-5050 needs lower amount of K.

\section{Effect of Sulfur}

Different rate of $\mathrm{S}$ result showed significant increased on the yield and yield contributing characters over control. Study revealed that $20 \mathrm{~kg} \mathrm{~S} /$ ha is enough in producing highest yield of fibre and stick. The combination dose of $\mathrm{N}_{100} \mathrm{P}_{15} \mathrm{~K}_{30} \mathrm{~S}_{20} \mathrm{~kg} / \mathrm{ha}$ may be enough for the advanced breeding line BJC-5050.

The preeminent FY and SY were found with the combination of $\mathrm{N}_{100} \mathrm{P}_{15} \mathrm{~K}_{30} \mathrm{~S}_{20} \mathrm{~kg} / \mathrm{ha}$. These results are strongly supported by the previous research results $[2-5,7]$.

\section{CONCLUSION}

It could be concluded that combined dose of NPK and S 100-15-30-20 kg/ha would be a suitable dose for the cultivation of advanced breeding line BJC-5050. The study evolved a technology which ultimately recommendation of fertilizer (NPK \& S 100-15-30-20 Kg/ha) for the advance line BJC-5050.

\section{ACKNOWLEDGEMENTS}

The author profoundly uttered gratefulness to Mrs. Suraiya Khandker-CSO, Dr. AKM Maqsudul Alam-CSO and finally Dr. Md. Nasimul Gani,CSO, BJRI for their brand support and encouragement for implementation of the research.

\section{REFERENCES}

1. BBS (Bangladesh Bureu of Statistics). (2012). Statistical Yearbook of Bangladesh. BangladeshBureau of Statistics, Ministry of Planning, Government of the Peoples Republic of Bangladesh.

2. Ali, M. S., Gani, M. N. and Islam. M. M. (2017). Efficiency of BJRI Kenaf-4 Yield Under Different Fertilizer Levels. American Journal of Agriculture and Forestry, 5 (5): 145-149.

3. Islam, M. M. and Rahman, M. M. (2008). In: Hand book on agricultural Technologies of Jute, Kenaf and Mesta crops. Bangladesh Jute Research Institute, Manikmia Avenue, Dhaka-1207, Bangladesh.

4. Alam, A. K. M. M., Khandker, S., Gani, M. N., and Ahmed S. A. (2000). Uptake addition and balance of nutrients under integrated fertilizer management in jute based cropping patterns. B. J. Sci. and Tech., 2 (2): 147-153. 
5. Sarker, A. K. and Bandopaddhay, P. K. (2000). Effect of potassium, boron and crop age on the yield and quality of white jute (Corchoruscapsularis). Indian Agr., 26: 212-216.

6. Das, K., Guha, B. and Pathak, D. (1996). Response of Capsularis to potassium fertilization. Ann. Agril. Res., 17 (2): 188-189.

7. Sarkar, S. K., Ghosh, R. K., Sounda, G., Maitra, S., Rux, D. K. and Ghosh, K. (1997). Effect of levels of nitrogen, potassium and soil moisture tension on growth, nutrient uptake and water use efficiency of jute. J Interacademia, 1 (3): 183-188.

8. Zheng, Z. H., Huang, Y. X. and Peng, X. J. (1984). Effects of additional K application to jute. China's Fiber Crops., 2: 1415.

9. Chew, W. Y., Malek, M. A. A. and Ramli, K. (1982). Nitrogen and potassium fertilization of congo jute (Urenalobata) and kenaf (Hibiscus cannabinus) on Malaysian peat. MARDI-Res. Bulletin, 10 (3): 317-322.

10. Gani, M. N., Alam, A. K. M. M., Khandker, S. and Ahamed, S. A. (1999). Biomass estimation of jute and its effect on soil. Bangladesh J. Sci. Res., 17 (2): 157-162.

11. Das, N. R. and Roy, M. (1999). Effect of $\mathrm{N}$ and seed rate on biomass production of rainfed jute (Corchorusolitorius L.). Ad. Plant Sci. Res. India., 9: 15-18.

12. Ali, M. S., Hossen, M., Ahmed, B., Gani, M. N. and Islam, M. M. (2017). Jute Seed Yield Response to Irrigation and Nitrogen Fertilization in Field-Grown Environment. International Journal of Biological and Environmental Engineering, 2 (2): 9-13.

13. Gomez, K. A. and Gomez, A. A. (1984). Statistical procedure for Agricultural Research. Second edn. John Wiley and Sons. Inc. New York. Pp. 304-307.

Citation: Md. Marfudul Hoque, Md. Saheb Ali, Md. Abdul Alim, Bornali Mostofa, Md. Mahbubul Islam. "Effective Nutrient Combination for Advance Capsularis Breeding Line BJC-5050 Production". American Research Journal of Agriculture, vol 5, no. 1, 2019, pp. 1-5.

Copyright (c) 2019 Md. Marfudul Haque, Md. Saheb Ali, Md. Abdul Alim, Bornali Mostofa, Md. Mahbubul Islam. This is an open access article distributed under the Creative Commons Attribution License, which permits unrestricted use, distribution, and reproduction in any medium, provided the original work is properly cited. 